\title{
AGRICULTURE AS A POSSIBLE WAY FOR SUSTAINABLE DISTRICT DEVELOPMENT IN BULGARIA
}

\author{
Zornitsa Stoyanova $^{1}$, Hristina Harizanova-Bartos ${ }^{2}$
}

\begin{abstract}
Agriculture is an important sector of Bulgarian economy and is a trigger for the development of rural areas. The analysis of district development takes into account the importance of European cohesion policy and national support for the achievement of smart, sustainable and inclusive growth. The main aim of this study is to reveal the place and the role of Bulgarian agriculture in rural development. Based on the clusterization on a district level we defined 3 clusters. The first one "economically poor - ecologically stable" has the highest probability for agricultural development and ability to transform into a well-developed agrarian cluster and to develop environmentally friendly activities and tourism. The second cluster -" economic developed" has potential for good prospects for the realization of the population, development of the diverse sectors, access to education and a high standard of living. The third cluster called "transitional - towards good economic development and ecologically unstable" has potential for the development of activities, including agrarian and use of new technologies to contribute to GDP per capita growth. The given policy recommendations are directed into the development of the three clusters. In the first cluster, policy makers should direct efforts to overcome the economic problems by transformation into a welldeveloped agrarian cluster. Cluster 2 is well developed and the policy should be directed at increasing the economic capacity of the studied areas. Cluster 3 is a transitional one and there the policy makers should try to develop a multifunctional way of transformation to sustainable territory for living.

The results are part of the scientific project DN 15/8 2017 Sustainable multifunctional rural areas: reconsidering agricultural models and systems with increased demands and limited resources funded by the Bulgarian research fund.
\end{abstract}

JEL Classification Numbers: Q01, Q10, R11, DOI: 10.12955/cbup.v7.1380

Keywords: rural development, agriculture, cluster analysis, policy recommendation

\section{Introduction}

There are different views on the roles of agriculture for rural development. Some authors consider agriculture a major sector for development (Corral et al., 2017). Others (Baldock, et al., 2001; Freshwater, 2000) share the opinion that the importance of agriculture for rural development is decreasing. A group of researchers focuses on climate change and the changing role of agriculture (Langlais et al., 2009; Reidsma et al.,2015). Nevertheless, in the focus of discussions, the importance of agriculture for the development of rural areas in economic, social, cultural and environmental terms and its changing role in new paradigm of scarcity of the resources is mentioned.

The main aim of this study is to reveal the place and the role of Bulgarian agriculture in rural development. This study has the following structure: 1) Literature review of relevant authors' findings directed to state the role of the agricultural sector in the development of rural areas; 2) the author's view about the application of Cluster Analysis for the Development of Territorial Units; 3) the methodological framework of the study; 4) the cluster analysis that is launched for distribution in Bulgarian districts; 5) an analysis is made according to the results for the importance of social, economic and ecological development of districts in Bulgaria and possible future development of Bulgarian districts is proposed. The results are part of the scientific project DN 15/8 2017 Sustainable multifunctional rural areas: reconsidering agricultural models and systems with increased demands and limited resources funded by the Bulgarian research fund.

\section{Literature review}

Authors such as Corral et al., (2017) consider that agriculture is the main driving force for rural economies by improving the incomes of the poor and the sources from which they earn their living. Copus et al., (2011) add that the economic aspect refers to the role and function of the land, the landscape and the environment as a source of economic activity in rural areas. They also surveyed the environmental processes and the role of agriculture in rural development as changing due to changes in the environment and climate change impact on rural development. Langlais et al., (2009) point out that climate change will affect economic activities in rural areas and will have an impact on agriculture and its importance. Climate change impacts will be significant in regions where agriculture and other key activities are still relatively important and in regions where there are highly developed activities such as "food consumption in rural areas". The survey states that regions in which economic diversification is developed will be less affected and diversification would be one way to reduce the expected impact of

\footnotetext{
${ }^{1}$ University of National and World Economy, Business faculty, Sofia, Bulgaria, zstoyanova@unwe.bg

${ }^{2}$ University of National and World Economy, Business faculty, Sofia, Bulgaria, h.harizanova@gmail.com
} 
climate change. An OECD (2010) study outlines how different types of activities and diversification from farm households can contribute to the expansion of economic activity in rural areas. Diversification from agricultural holdings can take a variety of forms: from increasing the range of agricultural products generated by the holding to the allocation of household production factors, to non-farm production activities. In this respect, diversification may contain changes in the way how households allocate their resources, also the results obtained from the use of these resources and the location of the activities. Reidsma et al., (2015) consider that climate change, technology, policy and prices impact on agriculture and rural development. They share a view that environmental impacts (global warming, terrestrial and water eutrophication) are negative, and in terms of social aspects (size of farm, number of farms, nature) the impacts are mixed. In this respect, in a period of climate change, there will be a change in both the impact of agriculture on rural development and its role for the development of the regions.

Some authors study the tendencies of the decreasing role of agriculture in rural areas. The study conducted by the OECD (2010) indicates that although farms contribute to the rural economy by creating employment and income generated by their agricultural and non-agricultural activities, there is a relative decline in the economic role of agriculture. High employment rates are often observed in rural areas, especially in those regions where transport connections are developed, urban centers are near or there is a potential for development of local assets. Agricultural activities can generate positive and negative externalities. According to Baldock, et al., (2001), intensification of agriculture occurs in areas where there is quality land and in more developed regions and the decreasing importance of agriculture is observed in poorer areas or where there is low quality land. The role of agriculture in rural development is also associated with demographic and economic changes that reduce the dependence of rural residents on the agricultural sector and other primary industries. However, new industrial productions occur which lead to the development of the services sector, but this statement is not relevant for the regions that suffer from the decline in their development. This view is shared also by Freshwater (2000), who considers that industrial production in rural areas increase in some regions, giving rural people opportunities for alternative employment. Reduction of the importance of agriculture and structural changes in economies has direct and indirect negative impacts on the economic results in rural areas.

\section{Application of Cluster Analysis for the Development of Territorial Units}

Clyster analysis is widely used method for developing a framework for territorial units. Often researchers use this method to trace out the dynamics in progress in the agricultural and rural development at a territorial level (Mazzocchi \& Montresor 2000.) They provide an analytical tool to simplify and interpret the results in order to supply a flexible instrument to policy-makers. Some of the main indicators which are used are GDP, unemployment rate, employed people in agriculture, and UAA. From the point of sustainable dimension, other authors used the cluster analysis to propose a distribution of water supply by clustering the territory with the level of water used in agriculture (Bartolini et al., 2007). Different types of cluster analysis are detailed and studied by Tiwari \& Misra (2011). They applied various tools such as cluster analysis for solving agricultural problems. The study is theoretical and includes several types of clusterization as fuzzy clustering, Hierarchical agglomerative clustering, Hierarchical divisive clustering, and Agglomerative clustering.

Industrial cluster distributions are proposed by Padmore \& Gibson (1998), who propose a system of innovation for industrial cluster analysis on a regional level.

From the social point of view, the distribution of the territory through cluster analysis is used by many authors where they mainly applied a cluster analysis according to the net income per capita (Guan \&Men, 2009).

Some authors applied the cluster analysis in agricultural sector for the distribution of dairy cattle farms (Harizanova et al., 2016).

Authors specialized in eco-economic use cluster analysis to propose an allocation of the polluted soils. The used methodology includes analysis by fuzzy c-means cluster analysis and non-linear mapping with data from 521 locations. The output is a map which can be used as a tool for policy implementations or developing special rules or regulations for the limitation of pollution (Hanesch et al., 2001).

\section{Data and methodology}

The analysis of district development takes into account the importance of European cohesion policy and national support for the achievement of smart, sustainable and inclusive growth. Bulgarian districts have 
a different level of development and for their proper understanding they should be grouped according to their economic, social and environmental status.

\section{Application of cluster analysis for the collected data}

Regions in Bulgaria are not equally developed and differ in the levels of their main macro indicators. In order to group and analyze them, several variables should be used. An appropriate method for achieving the desired result is cluster analysis and on this basis the 28 districts in Bulgaria were grouped. For the purpose of the research $\mathrm{k}$-means cluster will be used. K-means is a procedure where a starting point system is used to perform the analysis, which is also referred to as a name seed (Hair et al., 1998) or segments. In this way the segments form separate "point clusters", which are then merged until they can not be transferred to any other group with the corresponding variables. For this purpose, the Euclidean distance equation (1) is used.

\section{Euclidean distance}

$$
d_{i j}=\sqrt{\sum_{k=1}^{p}\left(x_{i k}-x_{j k}\right)^{2}}
$$

Source: Aldenderfer and Blashfield (1984)

For the need of the analysis 20 variables were tested for correlation after standardization of the data. The chosen variables are based on national statistics and include: economic development such as GVA, investments, incomes etc., demographic dynamics and social indicators. The data includes also variables for environment and agriculture. After reducing the correlated variables, a clusterization procedure is made for 3 clusters based on 7 variables, which are presented in Figure 1, while the distribution is presented in Table 1.

According to the information, clusters are characterized and named as is shown in Table 2.

\section{Analysis and development of clusters - Results and Discussion}

\section{Economic development}

For the 2001-2017 period, the average income per capita is increasing in all the clusters, respectively by $162 \%$ for Cluster 1,250\% for Cluster 2 and $233 \%$ for Cluster 3 . The highest average income per capita is in Cluster 3, followed by Cluster 2 and Cluster 3 is the lowest income observed. This is explained by poorly developed economic activities in areas in Cluster 1 and the presence of larger cities and industrial centers on the territory of Clusters 2 and 3.

\begin{tabular}{|l|l|c|c|}
\hline Table 1: Distribution of the clusters - Number of districts and their share in \%. \\
\hline \multirow{5}{*}{} & Districts & Number & Share in \% \\
\cline { 2 - 4 } & Cluster 1 & 5 & $18 \%$ \\
\cline { 2 - 4 } & Cluster 2 & 10 & $36 \%$ \\
\cline { 2 - 4 } & Cluster 3 & 13 & $46 \%$ \\
\hline & TOTAL & 28 & $100 \%$ \\
\hline Source: Authors
\end{tabular}

Figure 1: Cluster distribution of Bulgarian's districts

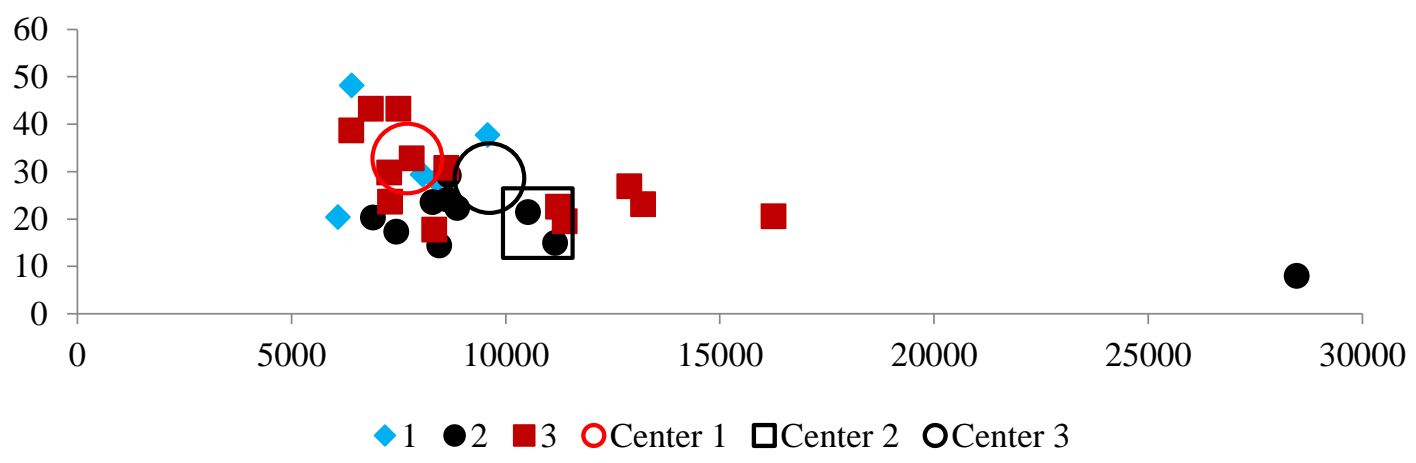

Source: Authors 


\begin{tabular}{|c|c|c|c|}
\hline Clusters & Characteristics & Given name & Positives/ potential \\
\hline $\begin{array}{l}\text { Cluster } \\
1\end{array}$ & $\begin{array}{l}\text { Low levels of GDP; } \\
\text { High share of } \\
\text { unemployment; } \\
\text { Low share of employment; } \\
\text { Low levels of carbon } \\
\text { dioxide emissions in the } \\
\text { atmosphere. }\end{array}$ & $\begin{array}{l}\text { Economically poor - } \\
\text { ecologically stable }\end{array}$ & $\begin{array}{l}\text { Ability to transform into a } \\
\text { well-developed agrarian } \\
\text { cluster; } \\
\text { Development of } \\
\text { environmentally friendly } \\
\text { activities and tourism; } \\
\text { Alternative employment. }\end{array}$ \\
\hline $\begin{array}{l}\text { Cluster } \\
2\end{array}$ & $\begin{array}{l}\text { High GDP, Low } \\
\text { unemployment rate; } \\
\text { A high share of } \\
\text { employment, } \\
\text { Large costs of acquiring } \\
\text { tangible fixed assets per } \\
\text { capita. }\end{array}$ & Economically developed & $\begin{array}{l}\text { Good prospects for the } \\
\text { realization of the population; } \\
\text { Diverse sectors; } \\
\text { Access to education; } \\
\text { A high standard of living. }\end{array}$ \\
\hline $\begin{array}{l}\text { Cluster } \\
3\end{array}$ & $\begin{array}{l}\text { High levels of carbon } \\
\text { dioxide emissions in the } \\
\text { atmosphere; } \\
\text { Low unemployment rates; } \\
\text { A large number of people } \\
\text { living below the poverty } \\
\text { line. }\end{array}$ & $\begin{array}{l}\text { Transitional - towards good } \\
\text { economic development - } \\
\text { ecologically unstable }\end{array}$ & $\begin{array}{l}\text { Development of activities, } \\
\text { including agrarian; } \\
\text { Use of new technologies to } \\
\text { contribute to GDP per capita } \\
\text { growth. }\end{array}$ \\
\hline
\end{tabular}

For the period 2000-2016, foreign investment is increasing in all three clusters by $90 \%$ each. During the analyzed period, foreign investment is the lowest in Cluster 1 - 477 euro / person. In Cluster 2, the highest amount of foreign investment was reported - 1361 euro / person on average for the analyzed period, followed by Cluster 3 with 1159 euro / person. This is also explained by the high level of unemployment in Cluster 1, the low GDP per capita and the relatively weak economic development of this cluster.

Demographic and social development

For the period 2001-2017, the urban population is increasing in all three clusters, but the most insignificant data of increase is observed in the third cluster - 1\%, and in the other two clusters observed which increase by $3 \%$. The share of the urban population is lowest in Cluster 1, with an average of 55\% over the analyzed period, and the highest cluster percentage is $69 \%$ on average, followed by Cluster 3 with $66 \%$ urban population.

Similar to the average per capita household income for the period 2003-2017, employment is increasing in all three clusters by around $13 \%$ in each. This is a trend for all areas, with an increase in employment ranging from about 5\% to about 13\%. In 2017, the highest employment rate is in Cluster $2(66.2 \%)$ followed by Cluster 3 to $64.7 \%$, and the lowest employment rate was observed in Cluster $1-58 \%$.

\section{Ecological development}

Comparison of clusters with respect to carbon emissions shows that Cluster 3 emissions are the highest while the lowest are seen in Cluster 1. This is explained by the low economic activity in Cluster 1 areas while the high level in Cluster 3 due to the fact that it includes some of the districts in Bulgaria where energy production is developed and emissions are emitted.

In Cluster 1, for the period 2010-2016 year the level of emissions decreased by 52\%, while in Cluster 2 and 3 a decrease of only $14 \%$ was observed. Reasons for higher carbon emissions, and relatively low level of reduction for the period 2010-2016 may be explained by the high GDP per capita as a result of greater economic activity. The dynamics is presented in a Figure 2.

The level of waste in all three clusters is decreasing in the period 2008-2016 with the highest rates of reduction seen in Cluster 3 with 32\% and the lowest in Cluster 2 with 27\% (Figure 3). The reduction of waste per capita can be explained by the promotion and raising of awareness for the management of waste, the implementation of waste treatment activities such as reusing and recycling and other 
environmental friendly practices leading to diverting waste from landfills. In the country, a positive trend towards improved waste management practices has been observed, as they have achieved national targets for household waste recycling, recovery and recycling of packaging waste and the objectives of recycling of waste stock (EEA, 2016). The reduction of waste in Cluster 2 is mostly due to the reduction of waste in the District of Pernik, where industrial production decreased for the analyzed period.
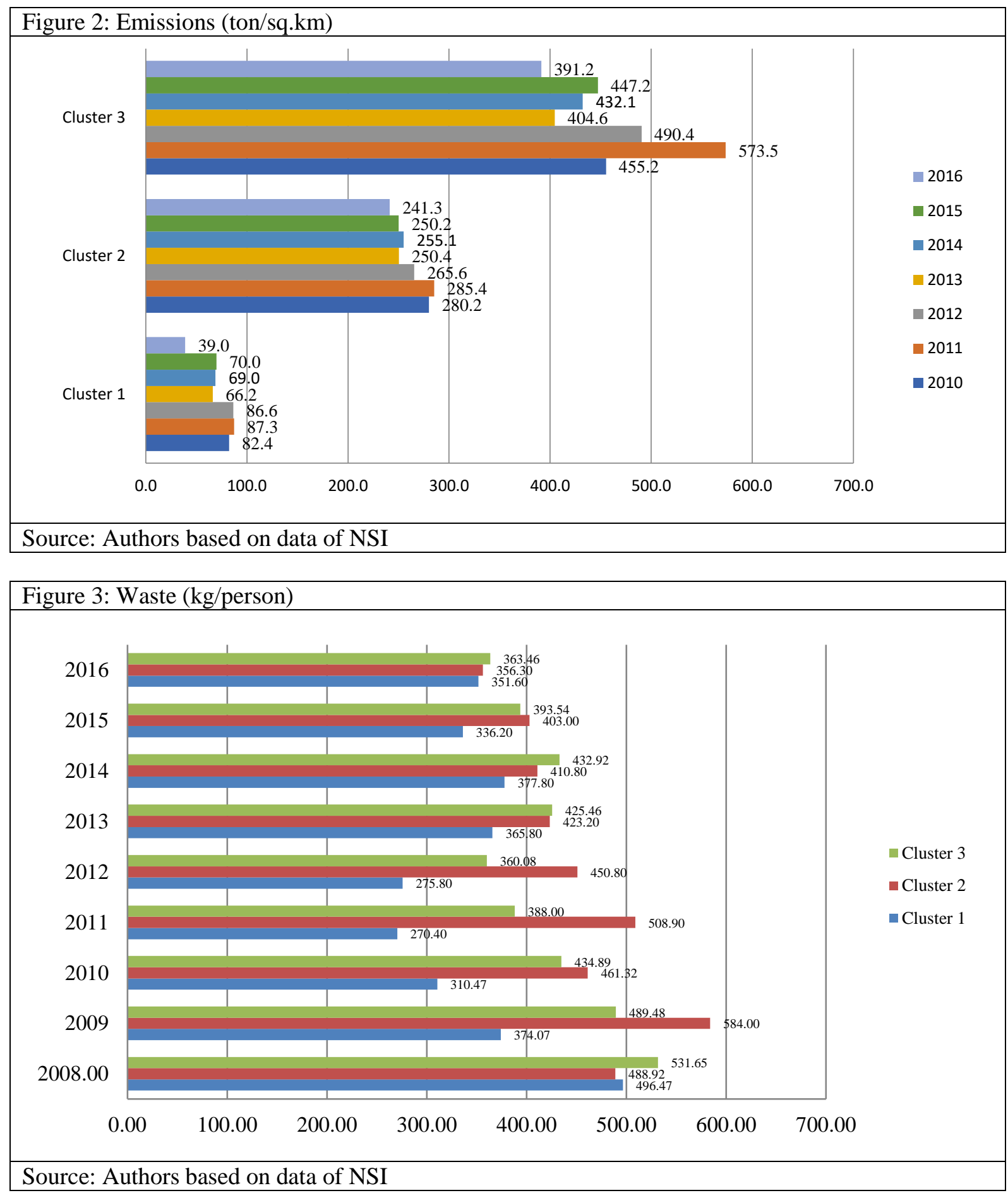

\section{Agriculture development as a way for sustainability in the areas - findings and conclusions}

From the collected data and clusterization at the district level, it can be concluded that Cluster 1 has the highest probability for agricultural development. This cluster has ability to transform into a welldeveloped agrarian cluster and to develop environmentally friendly activities and tourism. 
All districts which are in Cluster 1 have in their district development strategies have pointed towards agriculture development with high priority. The main conclusions of the perspectives and constrains of developing the sector can be summarized as follows:

\begin{tabular}{|c|c|}
\hline Current constrains and findings & $\begin{array}{ll}\text { Perspectives } \\
\end{array}$ \\
\hline $\begin{array}{l}\text { Existence of fragmented land as a result } \\
\text { of the process of restoration of land } \\
\text { ownership }\end{array}$ & $\begin{array}{l}\text { Fisheries and aquaculture are a specific sector that provides } \\
\text { employment of some of the population along the Danube coast and } \\
\text { in some areas of the Danube }\end{array}$ \\
\hline Slow rate of consolidation of the land & $\begin{array}{l}\text { The territory of the area in freshwater fish farming - fish farms and } \\
\text { dams }\end{array}$ \\
\hline $\begin{array}{l}\text { A large number of people living in other } \\
\text { regions of the country and abroad }\end{array}$ & $\begin{array}{l}\text { Agriculture is developing intensively and the production culture } \\
\text { in the sector is rising }\end{array}$ \\
\hline $\begin{array}{l}\text { Low rents paid by cooperatives and } \\
\text { landlords }\end{array}$ & $\begin{array}{l}\text { Suitable natural conditions for the development of organic } \\
\text { farming and the production of environmentally friendly products }\end{array}$ \\
\hline Low price of agricultural land & $\begin{array}{l}\text { High degree of usable agricultural land. } \\
\text { Preconditions for its development are the presence of high- } \\
\text { productive lands and favorable agro-climatic conditions }\end{array}$ \\
\hline $\begin{array}{l}\text { Lack of funds for farmers to apply } \\
\text { modern technology and use of modern } \\
\text { equipment }\end{array}$ & \\
\hline $\begin{array}{l}\text { Desertification of populated areas in } \\
\text { mountainous and semi-mountainous } \\
\text { areas }\end{array}$ & \\
\hline
\end{tabular}

In Cluster 2, 50\% of the district development program pointed towards agriculture as a main priority for development. According to the state of agriculture the perspectives and constrains are shown in Table 4.

\begin{tabular}{|l|l|}
\hline Table 4: Main findings and conclusions for agriculture development in Cluster 2 \\
\hline \multicolumn{1}{|c|}{ Current constrains and findings } & \multicolumn{1}{|c|}{ Perspectives } \\
\hline $\begin{array}{l}\text { The sector is the main source of income for the } \\
\text { population in the villages and in most for most } \\
\text { municipalities in the area, but GVA from it is } \\
\text { declining }\end{array}$ & $\begin{array}{l}\text { Diverse soil, climate and relief complex, favorable } \\
\text { to the development of agriculture }\end{array}$ \\
\hline $\begin{array}{l}\text { Absence of another alternative income and } \\
\text { employment, leads to increased migration of } \\
\text { working population }\end{array}$ & $\begin{array}{l}\text { Good conditions for intensive and environmentally } \\
\text { friendly farming; Beneficial complex of preserved } \\
\text { natural, anthropogenic environment and } \\
\text { biodiversity }\end{array}$ \\
\hline $\begin{array}{l}\text { In a difficult situation are the villages which GDP is } \\
\text { mostly by agriculture, tourism, forestry and } \\
\text { hydropower }\end{array}$ & $\begin{array}{l}\text { An important role in achieving sustainable } \\
\text { economic growth in the region will be the creation } \\
\text { of favorable economic conditions for the } \\
\text { development of modern agriculture and the } \\
\text { restoration of irrigation facilities and irrigation } \\
\text { systems }\end{array}$ \\
\hline Source: Authors
\end{tabular}

In Cluster 3, 92\% of the districts pointed towards the agricultural sector as a priority for development. The main findings and conclusions are shown in Table 5.

\section{Policy recommendations and conclusions}

According to the results and analysis made we can conclude that the development of the Bulgarian districts is not equal and some areas are lagging behind in their economic, social and ecological status. Based on clusterization of the territory into 3 clusters we can suggest that the policy makers should consider different policy goals for reaching sustainability. In Cluster 1 agriculture has a significant role for sustainability and this is the main priority given by the policy makers. Cluster 2 is mainly represented by districts where the population of the country is concentrated. The efforts of policy makers are important to support sustainable economic growth in the region by the creation of favorable economic conditions for the development of a modern and innovative economy. The most multifunctional cluster 
is the third one with the given name - Transitional - towards good economic development - and which is ecologically unstable. The policy should be directed to overcome the negative effect of the operating industry which pollute the area. On the other side, a good possibility for diversification of activities can be established in order to transform Cluster 3 into a stable and attractive place to live.

Table 5: Main findings and conclusions for agriculture development in Cluster 3

\begin{tabular}{|l|l|}
\hline \multicolumn{1}{|c|}{ Current constrains and findings } & \multicolumn{1}{|c|}{ Perspectives } \\
\hline $\begin{array}{l}\text { Highly productive and competitive products in the } \\
\text { field of plant and livestock breeding }\end{array}$ & Recovery of irrigated agriculture \\
\hline $\begin{array}{l}\text { Rich agro-ecological potential, which allows a } \\
\text { high degree of realization of the productive } \\
\text { capacities of the area }\end{array}$ & $\begin{array}{l}\text { Attracting investment in the processing agricultural } \\
\text { production industry }\end{array}$ \\
\hline $\begin{array}{l}\text { Favorable infrastructure for the development of } \\
\text { export-oriented production, including: the largest } \\
\text { and most modern port complex in Bulgaria and a } \\
\text { built-up system of rail and road transport }\end{array}$ & $\begin{array}{l}\text { Crossing of two phytogeographical zones - the } \\
\text { gediterranean and Mediterranean, as well as two zoo- } \\
\text { conditions are extremely rich in variety. There are rare } \\
\text { and endangered species included in the Red Book of } \\
\text { Bulgaria, endemic and relict species, and a wide variety } \\
\text { of valuable medicinal plants }\end{array}$ \\
\hline $\begin{array}{l}\text { The agro-climatic conditions are suitable for the } \\
\text { development of crops with a shorter vegetation } \\
\text { period due to the typical summer droughts }\end{array}$ & $\begin{array}{l}\text { Vertical integration of the famers; } \\
\text { Better connection with processors }\end{array}$ \\
\hline $\begin{array}{l}\text { The highly predominant mechanized cultivation of } \\
\text { mixed cultures engages less manual labor }\end{array}$ & $\begin{array}{l}\text { Implementing of new varieties - high yielding, resistant } \\
\text { to changing climatic conditions and a generally } \\
\text { growing crop of agriculture }\end{array}$ \\
\hline $\begin{array}{l}\text { A leading place in the country in terms of the size } \\
\text { of the agricultural areas occupied with perennial } \\
\text { plantations and mostly - wine vineyards. The } \\
\text { cultivation of wine grape varieties is conditioned } \\
\text { by the extremely favorable soil and climatic } \\
\text { conditions - as evidenced by the high quality wine } \\
\text { grape varieties used for raw materials in the wine } \\
\text { industry }\end{array}$ & $\begin{array}{l}\text { Collaboration between the science and the farmers } \\
\text { Source: Authors }\end{array}$ \\
\hline
\end{tabular}

\section{References}

Aldenderfer, M. S., \& Blashfield, R. K. (1984). Cluster analysis: Quantitative applications in the social sciences. Beverly Hills: Sage Publication. DOI https://epdf.pub/cluster-analysis-quantitative-applications-in-the-social-sciences.html.

Baldock, D., Dwyer, J., Lowe, P., Petersen J., Ward N. (2001). The nature of rural development: towards a sustainable integrated rural policy in Europe. IEEP. DOI http://assets.wwf.org.uk/downloads/nord_report_europe01.pdf.

Bartolini, F., Bazzani, G. M., Gallerani, V., Raggi, M., \& Viaggi, D. (2007). The impact of water and agriculture policy scenarios on irrigated farming systems in Italy: An analysis based on farm level multi-attribute linear programming models. Agricultural systems, 93(1-3), 90-114. DOI

https://www.researchgate.net/publication/4755674_The_impact_of_water_and_agriculture_policy_scenarios_on_irrigated_fa rming_systems_in_Italy_An_analysis_based_on_farm_level_multi-attribute_linear_programming_models.

Copus, A., Courtney, P., Dax, T., Meredith, D., Noguera , J., Talbot, H., Shucksmith, M. (2011). European Development Opportunities for Rural Areas. ESPON \& UHI Millennium Institute. DOI

https://www.espon.eu/sites/default/files/attachments/EDORA_Final_Report_Parts_A_and_B-maps_corrected_06-022012.pdf.

Corral, S., Díaz, A., Monagas, M., García, E. (2017). Agricultural Policies and Their Impact on PovertyAgricultural Policies and Their Impact on Poverty Reduction in Developing Countries: Lessons Learned from Three Water Basins in Cape Verde. Sustainability, 9(10). DOI https://doi.org/10.3390/su9101841.

EEA. (2016). National Environmental and Water Conservation Report. Sofia. DOI http://eea.government.bg/bg/soer/2016.

Freshwater, D. (2000). The evolution of rural policy and agricultural policy in North America. Sofia, Bulgaria. DOI https://pdfs.semanticscholar.org/b451/cefa250bd7a3d4dd31b10061e675d47ba1e2.pdf.

Guan, L., \& Men, K. P. (2009). Cluster analysis on per capita net income of rural households in China. Asian Agricultural Research,(1812-2016-142678), 1. DOI https://ageconsearch.umn.edu/record/53757/.

Harizanova-Metodieva, T., Gaidarska, V., \& Ivanova, T. (2016). Cluster analysis of dairy cattle farms. Zhivotnov'dni Nauki/Bulgarian Journal of Animal Husbandry, 53(3/6), 30-34. DOI https://www.cabdirect.org/cabdirect/abstract/20183030447. 
Hair, J. F., Anderson, R. E., Tatham, R. L., \& Black, W. C. (1998). Multivariate data analysis. 1998. Upper Saddle River. DOI https://is.muni.cz/el/1423/podzim2017/PSY028/um/_Hair_-_Multivariate_data_analysis_7th_revised.pdf.

Hanesch, M., Scholger, R., \& Dekkers, M. J. (2001). The application of fuzzy c-means cluster analysis and non-linear mapping to a soil data set for the detection of polluted sites. Physics and Chemistry of the Earth, Part A: Solid Earth and Geodesy, 26(11-12), 885-891.DOI https://doi.org/10.1016/S1464-1895(01)00137-5.

Langlais, R.,Tepecik Dis, A. (2009). Climate change. EDORA, Working Paper 8. DOI https://www.espon.eu/sites/default/files/attachments/EDORA_Final_Report_Part_C_WP1-22.pdf.

Mazzocchi, M., \& Montresor, E. (2000). A multivariate statistical approach to the analysis of rural development. Agricultural Economics Review, 1(389-2016-23371), 27. DOI http://ageconsearch.umn.edu/record/26455/files/01020027.pdf.

OECD. (2010). Agricultural policies and rural development - a synthesis of recent OECD work.DOI http://www.oecd.org/greengrowth/sustainable-agriculture/44668202.pdf.

Padmore, T., \& Gibson, H. (1998). Modelling systems of innovation: II. A framework for industrial cluster analysis in regions. Research policy, 26(6), 625-641.DOI https://ideas.repec.org/a/eee/respol/v26y1998i6p625-641.html.

Reidsma, P., Bakker, M., Kanellopoulos, A., Alam, S.,Paas, W., Kros, J., Vries W. (2015). Sustainable agricultural development in a rural area in the Netherlands? Assessing impacts of climate and socio-economic change at farm and landscape level. Agricultural System, 141, 160-173. DOI: 10.1016/j.agsy.2015.10.009.

Tiwari, M., \& Misra, B. (2011). Application of Cluster Analysis in Agriculture-A Review Article. International Journal of Computer Applications, 36(4), 43-7. DOI

https://pdfs.semanticscholar.org/5008/6405a4c42aaf05e641f184badecaaa4b3549.pdf. 